\title{
Hinweise für Autoren - Instructions to Authors
}

Bitte senden Sie Ihr Manuskript - in deutscher Oder englischer Sprache direkt an den Verlag S. Karger.

Das Manuskript soil in satzreifem Zustand in dreifacher Ausfertigung eingereicht werden. Die Entscheidung über die Aufnahme erfolgt auf-grund mehrerer Gutachten. Eine Kopie des Manuskripts soil grundsätz-lich beim Autor verbleiben.

Typographische Gestaltung und redaktionelle Bearbeitung sind dem Verlag vorbehalten. Übersteigen die Kosten der Autorkorrekturen 10\% der Satzkosten, müssen diese dem Autor in Rechnung gestellt werden. Dem Autor stehen 40 Gratissonderdrucke seiner Arbeit zu.

Verlagsrecht. Die Arbeit darf nicht gleichzeitig bei einer anderen Publi-kation eingereicht sein. Es ist Sache des Autors, die Nachdruckerlaubnis für Abbildungen, Tabellen usw. aus anderen Publikationen zu beschaf-fen. Mit der Annahme des Manuskripts zur Publikation gehen alle Rechte auf den Verlag über. Ohne schriftliche Genehmigung des Verlags dürfen diese Publikationen oder Teile daraus nicht in andere Sprachen übersetzt oder in irgendeiner Form mit mechanischen oder elektroni-schen Mitteln (einschließlich Fotokopie, Tonaufnahme und Mikroko-pie) reproduziert oder auf einem Datenträger oder einem Computersy-stem gespeichert werden.

Geschützte Markennamen müssen mit einem hochgestellten ${ }^{\circledR}$ bezeich-net werden. Die Verantwortung für die korrekte Befolgung dieser Vor-schrift liegt ausschließlich beim Autor. Abkürzungen bitte möglichst sparsam verwenden. Bei speziellen Abkürzungen jeweils beim ersten Auftreten das Wort ausschreiben und die später verwendete Abkürzung in Klammern folgen lassen: z.B. Adenosin-Monophosphat (AMP). Institutsangabe in der Sprache der Arbeit. Zusammenfassungen sollen 20 Schreibmaschinenzeilen nicht über-schreiten. Eine Fassung in englischer Sprache und der englische Titel der Arbeit müssen mitgeliefert werden, auch wenn die Arbeit in deutscher Sprache abgefaßt ist. In die Zusammenfassung gehören keine Li-teraturzitate, Tabellen, Abbildungen und Abbildungs- und Tabellenhin-weise sowie allgemein gehaltene Aussagen.

Schlüsselwörter in deutscher und englischer Sprache. Zu einer Arbeit gehören 3-5 Schlüsselwörter.

Tabellen, Abbildungen und Literaturzitate im Text erwähnen. Abbildungsvorlagen nicht aufkleben, lochen oder mit Büroklammern anheften; auf der Rückseite den Namen des Autors, den Titel des Bei-trags, die Angabe wo «oben» ist, sowie die Bildnummer angeben. Adresse des Autors am Schluß der Arbeit vollständig angeben. Literaturverzeichnis. Es soil nur die im Text zitierten Publikationen, diese dafür lückenlos, enthalten. Die Literatur ist entweder alphabetisch zu ordnen oder entsprechend der Reihenfolge im Text zu numerieren. Kurzmitteilungen/Short Communications. Für die Einreichung von Manuskripten gelten folgende Vorschriften:

Umfang max. 6 Schreibmaschinenseiten, max. 5 Literaturverweise, max. 1 Abbildung +1

Tabelle (oder wahlweise 2 Abbildungen oder 2 Tabellen). Gliederung nach üblichem Schema in Einleitung, Material und Methoden (Krankengut), Resultate, Diskussion, Literatur. Es ent-fallen Zusammenfassung/Summary, Schlüsselwörter/Key Words. Bitte senden Sie Manuskripte in 
Deutsch oder Englisch an den Verlag. Schwerpunkte von Kurzmitteilungen sollen neue Ergebnisse wissen-schaftlicher Arbeiten, auch in Form sogenannter Preliminary Communications/vorläufiger Mitteilungen, und auch neue Studienansätze -experimentell oder klinisch - sein. Verlag und Schriftleitung wollen er-reichen, daß solche Arbeiten innerhalb kürzester Zeit (ca. 8 Wochen) publiziert werden. Selbstverständlich bleibt es dem Autor überlassen, zu einem späteren Zeitpunkt eine ausführliche Fassung einzureichen. Please send your manuscripts, written in German or English, directly to S. Karger Publishers. The manuscript should be submitted in triplicate, ready for printing. Acceptance of a manuscript is based on the evaluation by several referees. The author should always keep a copy of the manuscript. The publisher reserves the right to edit the manuscript and decide on the layout. The author will be billed for corrections to the galley proofs entailing expenses in excess of $10 \frac{3}{8}$ of the original typesetting costs. The author is entitled to 40 free reprints of his article. Conditions. Once the manuscript is accepted for publication, all the rights will be retained by the publisher. The manuscript is received with the understanding that it is not under simultaneous consideration for publication elsewhere. It is the author's responsibility to obtain permission to reproduce illustrations, tables, etc. from other publishers. This publication, or parts of it, may not be translated into other languages, or reproduced by any mechanical or electronic means (including photocopying, recording and microcopying) or stored in a retrieval system without the publisher's written permission. Registered trade names must be marked with the superscript registration symbol ${ }^{\circledR}$. It is the sole responsibility of the author to ensure that this rule is followed properly.

Abbreviations. As few abbreviations as possible should be used. If the author wishes to abbreviate a term, this term should be written out in full when it first appears and followed in parentheses by the abbreviation that will henceforth be used: e.g. adenosine monophosphate (AMP).

The institute name and address should be given in the same language as the article.

Summaries should not exceed 20 typewritten lines. A summary in German and a German title must be submitted with the manuscript, even if the manuscript is in English. Summaries should not include any references, tables, figures, references to figures or tables, and general statements. Key words should be supplied in German and in English. Each article should have 3-5 key words.

Tables, figures and references must all be referred to in the text. Figures should not be pasted, perforated or fastened with paper clips; the back of each illustration should bear the author's name, the title of the article, the figure number and an indication as to which part of the figure is the top.

Author's address. The author's complete address should appear below the bibliography. Bibliography. It should include all (but only) the references that are cited in the text. The references may be arranged alphabetically or numbered according to their order of appearance in the text. Short Communications. The following rules apply to the submission of short communications:

Maximum length 6 typewritten pages, a maximum of 5 references, 1 figure +1 table (or either 2 figures or 2 tables). The paper should be divided as usual into Introduction, Material and Methods (Case Studies), Results, Discussion and References. No summary and key words are required. Please send your English or German manuscripts to the publisher. Short communications should be mainly concerned with results of scientific studies (also in the form of preliminary communications) and new experimental and clinical approaches. It is the aim of the 
publisher and the editorial board that these articles will be published as quickly as possible (approximately 8 weeks). The author is free to submit a more detailed version of the article at a later date. 